\title{
Valérie Loichot
}

The Tropics Bite Back: Culinary Coups in Caribbean Literature. Minneapolis:

University of Minnesota Press, 2013. xxxvii + 243 pp. (Paper Us\$25.0o)

This engaging, multilayered study proposes, poetically and superbly, "to analyze food in the Caribbean not only as a basic need but also as a form of cultural expression, a form of political resistance, and a form of civilization" (p. x), setting it apart from an increasing number of scholarly books on the subject. More than simply describing foods of creole/Caribbean provenance, or their preparation, within Caribbean texts of the French Caribbean as indices of cultural expression, Valérie Loichot analyzes food as a politic in multiple ways. She addresses food in the Caribbean as a "creole" trope of resistance, unbound "by clear spatial, political, or linguistic borders" (p. x), subverts the trope of cannibalism imposed upon Caribbean people as a means to enforce and legitimize their violent subjugation, and examines food as an index of exilic identifications serving to subvert colonial patterns of consuming the Caribbean and its people through sexual exchanges and exploitation. Finally, she shows how Caribbean writers have utilized "literary cannibalism" as an aesthetic mode to ingest, rewrite, reproduce and transform literary colonial texts to carve out a space moving Caribbean literature away from ongoing neocolonial literary cannibalism. Through five incisively written and insightful analytical chapters focusing on literary works by both male and female writers from Guadeloupe, Martinique, and Haiti, Loichot navigates the complex theoretical layers set out in her introduction to achieve a riveting study, ultimately to suggest that what is normally thought of as the domestic terrain of food/food preparation can be as subversive politically and aesthetically as the military coups that have shaken the Caribbean throughout its tumultuous, varied history.

The study begins with a thorough introduction outlining Loichot's theoretical paradigms of choice anchored in the notion of "Columbus's mistake"that is, Columbus's corruption of Carib Amerindians' self-naming, "caribá," as "caníbal," a term carrying with it etymological precursors linking the Amerindians to European myths of savage beasts and man-eaters. Loichot, of course, argues that this linguistic slippage or mishearing, on the part of Columbus and the conquistadores, served an ideological and economic purpose, that of displacing and inverting the violent acts of consumption that the colonial process itself entailed. Thus, the book "is as much about European and Western pathology as it is about the response of the object of the colonizing gaze" (p. xiv). Via Frantz Fanon, and others, Loichot exploits the connection colonial patterns consequently drew between "the edible and the cannibal" (p.xix), to show how Caribbean authors transform and reject the reduction of human beings to com-

(C) MYRIAM J.A. CHANCY, 2015 | DOI: 10.1163/22134360-08901029

This is an open access article distributed under the terms of the Creative Commons 
modities and cheap sources of labor (in all senses of the word). She extends the metaphors of both to métissage, exploring how ingestion and penetration, through the violence of colonization, inform each other, and yet also how the figure of the métis comes to function as a productive excess, "a subject instead of as waste" (p. xxix).

The first chapter of the book focuses on food metaphors and Édouard Glissant's use of them to articulate his concept of "creolization." Here Loichot astutely considers why Glissant chooses a dish (masala) that does not have obvious African roots to typify the Caribbean world. She argues that we have to think beyond the notion of the "circum-Caribbean" to complex networks of transculturation and adaptation. Having already demonstrated in her opening pages that hunger in the colonial imagination serves as a convenient means for legitimizing the starving of enslaved and subjected peoples to exploit their bodies for labor (both productive and reproductive), the second chapter addresses the themes of hunger and gluttony in works by Patrick Chamoiseau and Aimé Césaire. In her third chapter, Loichot turns to the already traveled ground of exile to demonstrate how culinary metaphors in domestic spheres serve as an index to the construction of postcolonial identities and reveal what is lost as individuals move out from Caribbean spaces in the works of Edwidge Danticat and Gisèle Pineau. The last two chapters refocus and extend the study to provide thought-provoking reconsiderations of the ways Dany Lafferière, Gisèle Pineau, Suzanne Césaire, and Maryse Condé subvert and invert colonial narrative by "cannibalizing" tropes of sexual and aesthetic consumption to arrive at a politic of mutuality. Given the little attention given to Suzanne Césaire's works in the field, the final chapter is illuminating.

While Loichot's analysis is persuasive throughout, a minor thread in the argument appears loose and unresolved: she argues that Caribbean authors come to establish "a literature in a postcannibalistic moment outside antagonistic or revengeful relations" (p. x). This notion returns at different junctures of the study, usually to argue that a text is not involved in "vengeful" thinking, making one wonder if this sub-theme in the analysis needed to be given voice at all. Ultimately, however, Loichot convincingly demonstrates that "culinary coups" form an aesthetic and a politic. As such, The Tropics Bite Back will serve as a compelling guide to students and scholars of Caribbean literature intent on navigating cultural tropes such as food and consumption not merely as manifestations of social organization, but as indicators of an integral aesthetic and a regional politic of liberation. 
Myriam J.A. Chancy

Department of Africana Studies,

University of Cincinnati, Cincinnati OH 45221, U.S.A.

myriam.chancy@uc.edu 